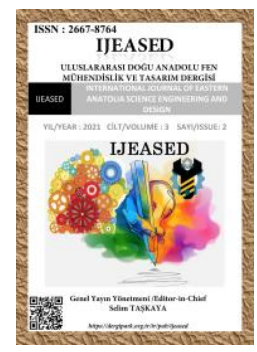

IJEASED INTERNATIONAL JOURNAL OF EASTERN ANATOLIA SCIENCE ENGINEERING AND DESIGN

\author{
Uluslararası Doğu Anadolu Fen Mühendislik ve Tasarım Dergisi \\ ISSN: 2667-8764, 3(2), 388-404, 2021 \\ https://dergipark.org.tr/tr/pub/ijeased
}

Araştırma Makalesi / Research Article Doi: $10.47898 /$ ijeased.964451

\title{
Yapı Sektöründe Baca Gazı Arıtma Atıklarının Araştırılması
}

\author{
Halide BOZKURT ${ }^{1 *}$, Cahide AYDIN İPEKÇI ${ }^{2}$
}

${ }^{1}$ Sakarya Uygulamalı Bilimler Üniversitesi, Hendek Meslek Yüksekokulu, Tasarım Bölümü, Sakarya, 54300, Türkiye.

${ }^{2}$ Gebze Teknik Üniversitesi, Mimarlık Fakültesi, Mimarlık Bölümü, Kocaeli, 41420, Türkiye.

\begin{tabular}{|c|c|c|}
\hline Yazar Kimliği / Author ID (ORCID Number) & \multicolumn{2}{|c|}{ Makale Süreci / Article Process } \\
\hline "Sorumlu Yazar / Corresponding author: & Geliș Tarihi / Received Date : & 07.07 .2021 \\
\hline halidebozkurt@subu.edu.tr & Revizyon Tarihi / Revision Date : & 29.08.2021 \\
\hline (iD) https://orcid.org/0000-0003-4023-7427, H. Bozkurt & Kabul Tarihi / Accepted Date : & 03.10 .2021 \\
\hline (iD https://orcid.org/0000-0003-3170-4628, C. Aydın İpekçi & Yayım Tarihi / Published Date & 15.12 .2021 \\
\hline
\end{tabular}

Alıntı / Cite : Bozkurt, H., Aydın İpekçi, C. (2021). Yapı Sektöründe Baca Gazı Arıtma Atıklarının Araştırılması, Uluslararası Doğu Anadolu Fen Mühendislik ve Tasarım Dergisi, 3(2), 388-404.

\section{Özet}

Kentlerdeki nüfus artışı ve sanayileşme enerji tüketimini arttırmaktadır. Enerji ihtiyacını karşılamak için yapılan termik santraller, doğal çevreye zarar veren büyük tesislerdir. Termik santrallerin çevresel etkilerini azaltabilmek için kurulan baca gazı arıtma (Flue Gas Desulphurization-FGD) sistemlerinin kullanımı ile baca gazı arıtma atıkları oluşmaktadır. $\mathrm{Bu}$ atıklardan FGD alçı (sentetik alçı) ve uçucu küller birçok ülkede yapı sektöründe yapı malzemesi üretiminde kullanılmaktadır. Atık ürünlerin malzeme üretiminde ham madde olarak kullanılması önemlidir. Bu çalışmada; Türkiye'de kömür yakıtlı termik santrallerdeki baca gazı arıtma sistemlerinde oluşan atıkların yapı sektöründeki kullanım olanakları araştırılmıştır. Bu kapsamda; baca gazı arıtma atıklarına yönelik literatür araştırması yapılmış ve Türkiye'de baca gazı arıtma sistemi bulunan kömür yakıtlı termik santraller ile görüşme yapılarak oluşan atıkların nasıl değerlendirildiği tespit edilmeye çalışılmıştır. Sonuç olarak, FGD alçı atığı alçı levha; uçucu küller ise çimento üretiminde kullanılmaktadır. Baca gazı arıtma atıklarının yapı sektöründe kullanım olanakları termik santrallerin teknik ve teknolojik açıdan gelişmiş olmasına bağlıdır. Bu atıkların yeniden kullanılabilirliğini sağlamak depolama alanlarına gönderilen atık miktarının azaltılmasına katkı sağlayacaktır.

Anahtar Kelimeler: Yapı Sektörü, Baca Gazı Arıtma Atıkları, FGD Alçı, Atık Yönetimi. 


\title{
Investigation of Flue Gas Desulphurization (FGD) Wastes in the Construction
}

\author{
Industry
}

\begin{abstract}
Population growth and industrialization in cities increase energy consumption. Thermal power plants built to supply the energy requirement are large facilities that harm the natural environment. Flue Gas Desulphurization (FGD) wastes are generated as a result of FGD systems established to reduce the environmental impacts of thermal power plants. FGD gypsum (synthetic gypsum) and fly ash, which are among these wastes, are used for building materials production in the construction sector in many countries. In this study; the usage possibilities of FGD wastes generated as a result of FGD systems in coal-fired thermal power plants in Turkey have been investigated in the construction sector. In this context; a literature search has been conducted on FGD wastes and it has been tried to determine how the wastes generated by interviewing the coal-fired thermal power plants with FGD system in Turkey are evaluated. As a result; FGD gypsum waste is used in gypsum board production, and fly ash is used in cement production. The usage possibilities of FGD wastes in the construction sector depend on the technical and technological development of thermal power plants. Providing the reusability of these wastes will contribute to reduction of the amount of waste sent to landfills.
\end{abstract}

Keywords: Construction Industry, Flue Gas Desulphurization Wastes, FGD Gypsum, Waste Management.

\section{Giriş}

Günümüzde dünya nüfusunun artışı, sanayileşme ve kentsel yapılaşma faaliyetleri enerji tüketiminin hızlı bir şekilde artmasına neden olmaktadır. Enerji ihtiyacının karşılanabilmesi için ise çeşitli enerji kaynakları kullanılmaktadır. Bu kaynaklardan biri olan elektrik enerjisi, tüketim payının 2020'de \%19,1'e, 2040'ta ise \%22,9'a çıkması beklenen ve 2040 yılına kadar en hızlı büyüyen enerji türüdür. 2016 yılı verilerine göre dünyada birincil enerji kaynaklarının tüketiminin \%85'ini fosil yakıtlar oluşturmaktadır (TETAŞ, 2018). Dünya çapında enerji üretiminde siyah ve kahverengi kömür gibi ham maddelerin kullanılmasının devam edeceği tahmin edilmektedir (Wright ve Khatib, 2016). 2016-2040 yılları arasında elektrik üretiminde kömürün en önemli kaynaklar arasında olacağı öngörülmektedir. Elektrik üretiminde kömürü yüksek oranda kullanan ülkeler arasında; Güney Afrika Cumhuriyeti $(\% 92,6)$, Polonya $(\% 83,7)$, Kazakistan $(\% 81,3)$, Çin $(\% 74,7)$, Hindistan $(\% 72,7)$, Avustralya $(\% 64,6)$, İsrail $(\% 54,7)$, Endonezya $(\% 51,2)$, Çek Cumhuriyeti $(\% 47,9)$, Almanya $(\% 44,6)$, ABD $(\% 39,7)$ ve Japonya $(\% 28,5)$ sayılabilmektedir (Tamzok, 2017). Türkiye ise 2019 yılında üretilen elektriğin \%37,4’i kömürden elde etmiştir (EÜAŞ, 2020). Türkiye' de kömüre dayalı ilk termik santral 1914 y1lında Osmanlı Anonim Elektrik Şirketi tarafindan İstanbul'da kurulan Silahtarağa Santrali'dir (Tamzok, 2017). Günümüzde ise, Çevre ve Şehircilik Bakanlığı’nın Sanayi Kaynaklı Hava Kirliliğinin Kontrolü Yönetmeliği’ne göre kurulu gücü $50 \mathrm{MW}$ ve üzeri olan ‘Büyük Yakma Tesisi’ olarak adlandırılan kamu ve özel sektöre bağlı 30 adet kömür yakıtlı termik santral bulunmaktadır (Enerji Atlası, 2019). 
Elektrik enerjisi üretimi için kömür yakıtlı termik santrallerin faaliyetleri sonucu oluşan çeşitli atıklar; hava, su ve toprak kirliliğine neden olan çevresel sorunlara yol açmaktadır. Termik santrallerdeki baca gazları, kül stok sahasındaki küller, kül barajları, kül siloları, kül nakil bant hattı, hidrolik kül atma sistemi, santral sahası, dekapaj sahası, açık kömür işletme sahaları, kömür nakil yolları, kirli atık sular ve termal etki gibi faktörler çevreyi olumsuz yönde etkilemektedir (Karaca vd., 2009). Fosil yakıtlar, yanma sırasında kükürt dioksit $\left(\mathrm{SO}_{2}\right)$, azot oksit $\left(\mathrm{NO}_{\mathrm{x}}\right)$ ve karbon dioksit $\left(\mathrm{CO}_{2}\right)$ gibi hava kirliliğinde önemli bir rol oynayan maddeleri yaymaktadır. Bu maddeler, bitkilerin büyümesini engelleyebilecek, tatlı su alanlarını kirletebilecek ve hatta binaların bozulmasını sağlayan asit yağmurlarının oluşmasına neden olmaktadır (Wright ve Khatib, 2016). Birçok ülke, hava kirliliğinin çevre üzerindeki etkileri ile mücadele etmek için standartlar ve mevzuatlar uygulamaktadır. $\mathrm{Bu}$ doğrultuda kömür yakıtlı termik santrallerin gaz emisyonlarını $\left(\mathrm{SO}_{2}, \mathrm{CO}_{2}\right)$ azaltabilmek için "baca gazı arıtma (Flue Gas Desulphurization-FGD)” sistemleri geliştirilmiştir. FGD sistemlerinin kurulumunda yatırım maliyeti ve santral performansı önemli bir yere sahiptir (TÜBİTAK, 2013). Tesis tipi ve kükürt giderme işlemi için yapılan kurulum, sistemin verimliliğine etki etmektedir. Kükürt giderme süreci sonucunda oluşan atıkların miktarı ve kalitesi; ham maddelere ve işlemin içeriğine bağlı olarak değişiklik göstermektedir. FGD sistemleri; 1slak sistem, yarı ıslak sitem ve kuru sistem olmak üzere 3'e ayrılmaktadır. Islak sistem; uygulama, işletme ve devamlılık açısından ekonomik olarak yarı ıslak veya kuru sistemlere göre daha pahalıdır. Ancak oluşan atık malzemelerin miktarı ve saflığı açısından en fazla çevre dostu olan sistemdir (Wright ve Khatib, 2016). FGD tesisine sahip termik santrallerin çoğunluğu ABD, Almanya ve Japonya'da bulunmaktadır (Çift, 2008). Dünya genelinde 1990'lı yıllarda 600'ün, 2005 yılında ise 900'ün üzerinde; Türkiye'de ise 1990'lı yıllar sonrasında kamuya bağlı büyük ölçekli termik santrallerde FGD tesisi kurulmaya başlandığı bilinmektedir. (Wright ve Khatib, 2016; Aytaç, 2020). Değişen çevre koşulları ile özel ve kamuya bağlı santrallerin sayısı artmış, FGD tesisi kurulu büyük ölçekli termik santral sayısı 2018 yılında 18, 2020 yılında ise 21'e yükselmiştir (Aytaç, 2018; Aytaç, 2020).

Termik santrallerde FGD sistemlerinin kullanılması sonucunda çeşitli FGD atıkları ortaya çıkmaktadır. Bu atık maddeler inorganik bileşikler olup, genel olarak, $\mathrm{SO}_{2}$ gazlarını kireçtaşı gibi alkalin emici maddelerle reaksiyona sokarak alçıtaşı $\left(\mathrm{CaSO}_{2}-2 \mathrm{H}_{2} \mathrm{O}\right)$ gibi çözünmeyen atıklar oluşturmaktadır (Wright ve Khatib, 2016). Emisyon temizleme işlemi sonucunda ortaya çıkan bu atıklar sentetik ürün olup, "FGD alçı" veya "sentetik" olarak da adlandırılmaktadır. Termik santral atıklarının çeşitli sektörlerde kullanımına yönelik çalışmalar bulunmakta olup, FGD alçının, doğal alçının kullanıldığı tüm alanlarda değerlendirilme özelliklerine sahip olduğu bilinmektedir. Termik 
santrallerden kaynaklı çevre sorunlarını önleyebilmek, doğal kaynakları koruyabilmek, depolama sahalarına gönderilen atık miktarını ve ham maddeye olan ihtiyacı azaltabilmek için bu atıkların değerlendirilmesi ve üretim sürecine dahil edilmesi önemli bir konudur.

Bu çalışmada; Türkiye'de kömür yakıtlı termik santrallerde baca gazı arıtma işlemi sonucunda oluşan FGD alçısının yapı sektöründe kullanım olanaklarının araştırılması amaçlanmıştır. Konu kapsamında literatür araştırması yapılmış ve FGD sistemine sahip termik santrallerden 3 tanesinin tesis yetkilileri ile görüşme yapılarak bu atıkların yapı sektöründe yeniden kullanımına veya geri dönüşümüne yönelik durum tespit edilmeye çalışılmıştır. Termik santral atıklarının değerlendirilmesine yönelik yapılan çalışmaların geliştirilmesinin çevresel ve ekonomik açıdan faydalı olacağı, ayrıca doğal alçıtaşı kaynaklarının korunmasına da katkı sağlayacağı düşünülmektedir.

\section{Baca Gazı Arıtma Atıkları}

FGD atıkları, termik santrallerde baca gazı kükürt giderme sistemindeki emisyon temizleme işlemi sonucunda ortaya çıkan ürünlerdir (Dunster, 2007). Bu ürünler, $\mathrm{SO}_{\mathrm{x}}$ gazlarının tutulması ile birlikte kalsiyum sülfit hemihidrat $\left(\mathrm{CaSO}_{3} .0 .5 \mathrm{H}_{2} \mathrm{O}\right)$ veya kalsiyum sülfat dihidrat $\left(\mathrm{CaSO}_{4} .2 \mathrm{H}_{2} \mathrm{O}-\right.$ alçıtaşı) esaslı çamurdan oluşmaktadır. FGD çamurunun fiziksel özelliklerini; partikül büyüklüğü, nem miktarı, birim hacim ağırlığı ve sıkışabilirliği belirlemekte olup, bu özellikler çamurun işlenmesini, taşınmasını, kurutulmasını ve su kapasitesini etkilemektedir. Dünyadaki FGD atıkları, santralden santrale göre değişiklik göstererek büyük miktarlara ulaşmış durumdadır (Tülek, 2007). FGD ürününün özellikleri kullanılan kömürün cinsine, uçucu kül içeriğine, kullanılan reaktif maddeye ve ürünün oksidasyon miktarına bağlıdır (Yazıcı, 2004). Termik santrallerde elektrik üretmek için kömür kullanılması değişik nitelikte atık malzeme oluşumuna neden olmaktadır. 02.04.2015 tarih ve 29314 sayılı Resmi Gazetede yayımlanan Atık Yönetimi Yönetmeliği'ne göre; kömür yanması sonucu oluşan atıklar 'Isıl İşlemden Kaynaklanan Atıklar' olarak tanımlanmaktadır. Bu atıklar; uçucu kömür külü, cüruf ve kazan tozu, sülfürik asit, dip külü ve baca gazı kükürt giderme işleminden elde edilen kalsiyum bazlı katı atıklar ve çamurlardır (ÇŞB, 2015).

FGD atıkları $\mathrm{SO}_{2}$ içeriğine göre 4 grupta sınıflandırılabilir (Wright ve Khatib, 2016):

1.Silikatsız ve Zararlı Reaktif Atıklar; çimento bazlı malzemelerde kullanıldı̆̆ında, mukavemet kaybı gibi, bağlayıcı gelişimi üzerinde zararlı bir etkiye sahip olan 1slak FGD 
işlemlerinden elde edilen FGD alçısından oluşmaktadır. Bu malzemelerin bileşimi, normal olarak alçı şeklindeki kalsiyum sülfat olup, $\mathrm{SO}_{2}$ içeriği yaklaşık \%35-50'dir.

2.Zararsız ve Reaktif Olmayan Atıklar; kuru ve yarı ıslak baca gazı temizliği sonucunda oluşmaktadır. Genel olarak bu malzemeler reaktif olmayan formda kalsiyum sülfat / sülfit içererek $\mathrm{SO}_{2}$ içeriği yaklaşık \%20-30'dur.

3.Silisli ve Puzonalik Olmayan Aktif Atıklar; genellikle yakma işlemi sonucunda elde edilen taban külleridir. $\mathrm{Bu}$ malzemelerin $\mathrm{SO}_{2}$ içeriği yaklaşık \%10-15'tir.

4. Silisli ve Puzolanik Aktif Atıklar; yakma işleminden gelen uçucu küller ile kuru ve yarı 1slak baca gazı temizliği sonucunda oluşmaktadır. Bu malzemelerin $\mathrm{SO}_{2}$ içeriği yaklaşık \%10 veya daha azdir.

\subsection{FGD Alçı}

FGD alçı, kömür yakıtlı elektrik üretim istasyonlarında baca gazının ıslak sistem ile kükürtsüzleştirilmesi sonucu oluşan inorganik bir bileşiktir (Tülek, 2007). Islak sistemde ortaya çıkan atık alçı doğal alçıdan \%96 daha yüksek saflık oranına sahiptir. Bu sistemde; kireçtaşı, sönmüş kireç gibi alkali bir sorbent haline getirilerek baca gazlarına püskürtülen sönmüş kireç ve uçucu külün bir karışımı kullanılmaktadır. En yaygın yöntem, bir sorbent olarak kireçtaşının kullanılarak kalsiyum bileşiği oluşturmak üzere $\mathrm{SO}_{2}$ gazlarıyla tepkimeye girmesi ve kalsiyum sülfat $\left(\mathrm{CaSO}_{4}\right.$. 2 $\mathrm{H}_{2} \mathrm{O}$-alçıtaş1) üretmek için işlem görmesidir (Wright ve Khatib, 2016). Saf alçıtaş1 üretmek ve atmosferdeki asit çökelmesinin azaltılması için ince ögütülmüş kireç taşı kullanılmaktadır. $\mathrm{Bu}$ süreçte, depolama tankında oluşan FGD alçı çamuru filtreleme ve susuzlaştırma işlemleri ile FGD alçı olarak kullanılabilmektedir. Kükürtsüzleştirme sürecinde açığa çıkan $\mathrm{CO}_{2}$ Denklem 1'de, sslak arıtma sistemi ile FGD alçı oluşumu şematik olarak Şekil 1'de gösterilmiştir (Dunster, 2007). Baca gazı arıtma çalışmaları sırasında kullanılan kömürün kükürt içeriğine ve miktarına bağlı olarak farklı özelliklerde atık ürünler ortaya çıkmaktadır. Termik santrallerde \%1 oranında $\mathrm{SO}_{2}$ içeren kömür kullanılması, toplam miktarın yaklaşık olarak \%5'i oranında FGD alçı ve \%10’u oranında kül oluşumuna neden olmaktadır. Bu durumda; \%1 oranında sülfür içeren 100 kg kömürün yakılması sonucunda açığa çıkan atık miktarları Şekil 2'de şematik olarak gösterilmiştir. (Coppola ve ark., 1996).

$\mathrm{CaCO}_{3}\left(\right.$ kat1) $+\mathrm{SO}_{2}$ (gaz) $\rightarrow \mathrm{CaSO}_{3}\left(\right.$ kat1) $+\mathrm{CO}_{2}($ gaz)

Kireçtaş1 + Kükürtdioksit $\rightarrow$ Kalsiyum Sülfit + Karbondioksit 


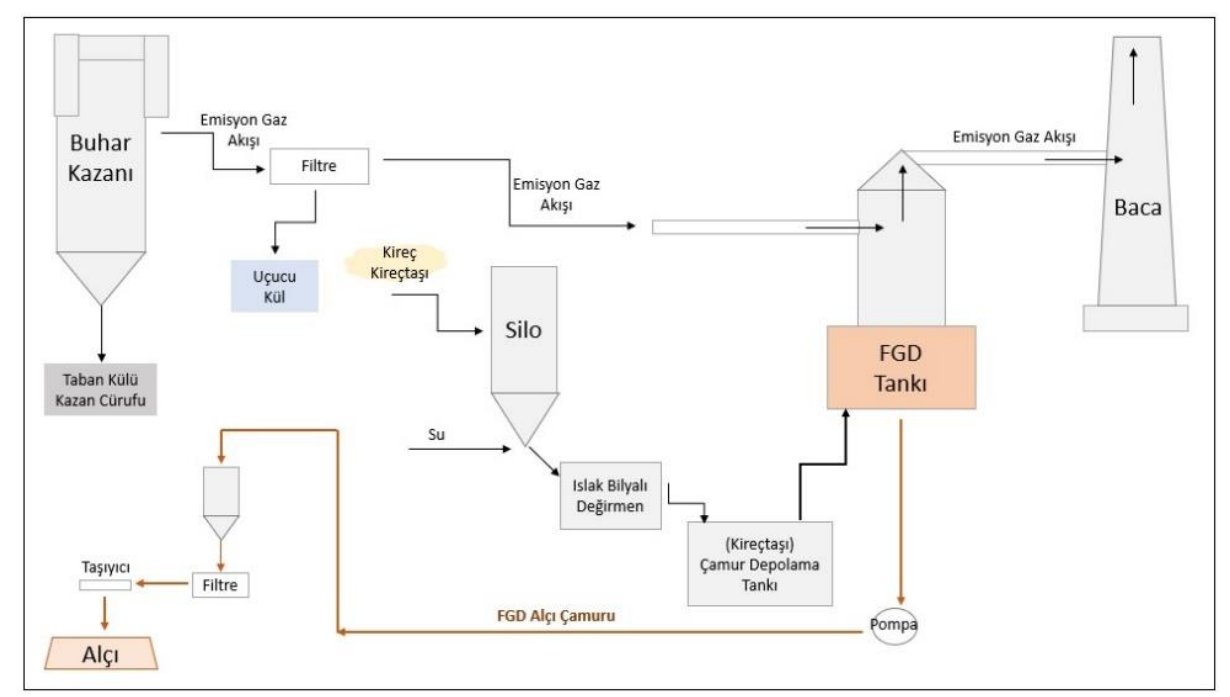

Şekil 1. Islak Arıtma İşlemi ile FGD Alçı Oluşumu

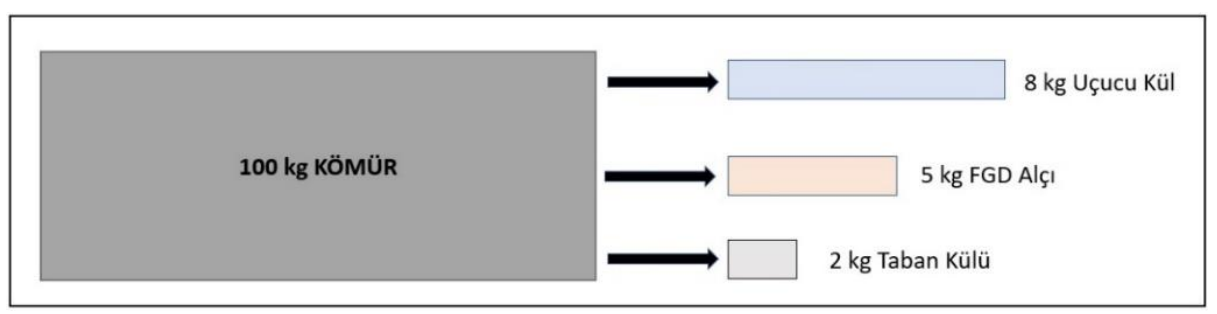

Şekil 2.100 Kg Kömürün Yakı1ması ile Oluşan Atık Miktarları

Atık Yönetimi Yönetmeliği Ek-4’te verilen atık listesine göre FGD alçı, sistemden katı halde çıkıyorsa 10-01-05 kodlu "baca gazı kükürt giderme işleminden (dezülfürasyon) çıkan kalsiyum bazlı katı atıklar", çamur halinde çıkıyorsa 100107 kodlu "baca gazı kükürt giderme işleminden (dezülfürasyon) çıkan kalsiyum bazlı çamurlar” olarak kodlanmıştır (ÇŞB, 2015). FGD alçının; miktarı, partikül büyüklüğü, saflığı, kimyasal ve fiziksel özellikleri açısından yapı malzemelerinde alternatif ham madde olarak kullanılması mümkündür (Xu ve ark., 2017). FGD alçı; susuzlaştırılarak alçı duvar levhası yapımında veya tarımsal amaçlı zemin ıslahı ve toprak koşullandırma amacıyla, uçucu kül veya şist ile harmanlanarak çimento yapımında, anhidrit zemin şaplarında, bina sıvalarında, yol yapımında ve gübre üretiminde kullanılabilir (Dunster, 2007; ÇŞB, 2016). Diğer FGD atıkları ise, ham madde olarak beton veya duvar bloklarında kullanılabilen geri dönüştürülmüş hafif agrega ve çimento üretimi gibi inşaat sektörü içerisindeki çeşitli alanlarda kullanılmaktadır (Wright ve Khatib, 2016). Şekil 3'te FGD alçının yapıda kullanım süreci şematik olarak gösterilmektedir. Termik santral atığı olan FGD alçı, üretim süreci öncesinde doğal alçı gibi ham madde olarak çıkartılma ve kırma işlemleri uygulanmadan öğütme ve kurutma işlemleri 
sonrasında tesis alanına taşınarak yapı malzemesi üretimi için prosese dahil edilmektedir. Üretim süreci sonunda doğal alçı kullanımı ile benzer özellik gösteren ürün olarak yapıda kullanılmaktadır.

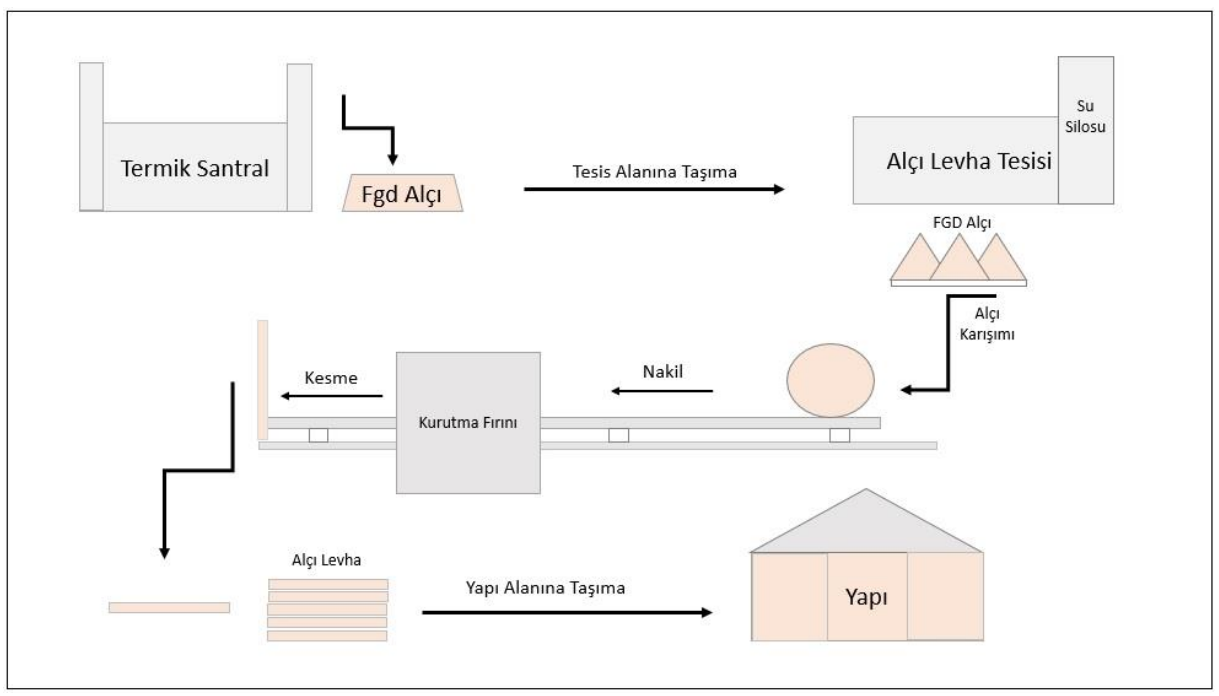

Şekil 3. FGD Alçının Yapıda Kullanımı

İngiltere'de 1994 yılından itibaren doğal alçı yerine FGD alçı kullanılmaktadır. FGD alçının alçı levha üretiminde kullanılmasına yönelik talebin artması FGD alçı üreten tesislerin kurulmasına olanak sağlamıştır. İngiltere'deki alçı levha üreticileri, teknik özellikleri karşılayan alternatif ham maddelerin kaynaklarını değerlendirerek FGD alçı kaynaklarının kullanımını arttırmaktadırlar. FGD alçıya ek olarak titanogypsum ve fluorogypsum gibi yan ürün alçılar da oluşmaktadır. İngiltere'deki FGD alçı ve yan ürün alçıların kullanım durumu ve üretim miktarı Tablo 1'de (Dunster, 2007), FGD alçının; malzeme, ekonomik, yasal, çevresel ve organizasyonel açılardan kullanımına yönelik potansiyel faydaları ve potansiyel engelleri Tablo 2'de gösterilmektedir (Dunster, 2007). Çek Cumhuriyeti'nde kalsine alçı üretiminde karbon ayak izi analizine göre ham madde olarak doğal alçı ile FGD alçının yaşam döngüleri boyunca harcadıkları enerji miktarı karşılaştırıldığında, çevresel etki açısından FGD alçı kullanımında doğal alçıya göre \%25 daha az enerji harcandığı saptanmıştır (Fort ve Cerný, 2018). Alçı sıvanın üretiminde ham madde olarak doğal alçı yerine FGD alçı kullanımı madencilik faaliyetlerini azaltmaktadır. Baran ve ark. (2021)'nın çalışmasına göre; alçı sıvanın yaşam döngüsü kapsamında ham madde temini, ulaşım ve üretim aşamalarındaki (A1-A3) çevresel etkileri değerlendirildiğinde doğal alçı kullanımının FGD alçı kullanımına oranla iki kat küresel ısınma potansiyeline etki ettiği sonucuna varılmıştır. Alçı malzeme üretiminde geri dönüştürülmüş ürünlerin kullanılması ham maddeye olan ihtiyacı ve oluşan $\mathrm{CO}_{2}$ miktarını azaltacaktır. 
Tablo 1. İngiltere'de Yan Ürün Alçı Kaynakları

\begin{tabular}{clc}
\hline Yan Ürün Alçı Tipi & Mevcut Kullanımı & $\begin{array}{c}\text { Mevcut Üretim } \\
\text { (Milyon Ton / Yıl) }\end{array}$ \\
\hline $\begin{array}{c}\text { FGD Alçı (Kömür yakıtlı elektrik } \\
\text { santrallerinin baca gazlarından kükürt } \\
\text { dioksitin uzaklaştırılması) }\end{array}$ & $\begin{array}{c}\text { Tamamına yakın bir bölümü } \\
\text { alçıpan veya ilgili ürünlerde }\end{array}$ & 1.4 \\
\hline $\begin{array}{c}\text { Titanogypsum (TiO, pigment } \\
\text { üretiminden) }\end{array}$ & Çoğunluğu alçıpan veya arsada & 0.48 \\
\hline $\begin{array}{c}\text { Fluorogypsum (Hidroflorik asit } \\
\text { üretiminden) }\end{array}$ & Çimento ve zemin şaplarında & 0.04 \\
\hline
\end{tabular}

Tablo 2. FGD Alçının Potansiyel Faydaları ve Potansiyel Engelleri

\begin{tabular}{|c|c|c|}
\hline & Potansiyel Faydalar & Potansiyel Engeller \\
\hline Malzeme & $\begin{array}{c}\text { Doğal kaynaklardan daha yüksek saflığa } \\
\text { sahiptir }\end{array}$ & $\begin{array}{l}\text { Taşıma ve depolama sorunu mevcuttur. } \\
\text { Malzeme için kurutma işleminde enerji } \\
\text { gerekmektedir. }\end{array}$ \\
\hline Ekonomik & İthal ham maddeden daha ucuzdur & - \\
\hline Yasal & - & $\begin{array}{l}\text { FGD alçı hala atık olarak } \\
\text { tanımlanmaktadır. }\end{array}$ \\
\hline Çevresel & $\begin{array}{l}\text { Yanma kalıntıları geri dönüş̧ürülerek doğal } \\
\text { kaynakların korunumu sağlanmaktadır. }\end{array}$ & $\begin{array}{l}\text { Kireç üretimi sürecinde karbon dioksit } \\
\text { açığa çıkmaktadır. }\end{array}$ \\
\hline Organizasyonel & $\begin{array}{l}\text { Yaygın olarak kullanılarak endüstriyel } \\
\text { düzenlemeler için yüksek potansiyele sahiptir. }\end{array}$ & $\begin{array}{l}\text { Uzun vadede kömür yakıtı kullanılarak } \\
\text { elektrik üretimi belirsizdir. Atık olarak } \\
\text { değerlendirilme durumu mevcuttur. }\end{array}$ \\
\hline
\end{tabular}

Çin'de 2015 yılı verilerine göre; 80 milyon ton FGD alçı üretilmiştir (Xu ve ark., 2017). Avrupa Kömür Yakma Ürünleri Derneği’nin 2016 y1lı verilerine göre, 40,33 milyon ton termik santral atığının 9,91 milyon tonunu FGD alçı oluşturmaktadır (URL-1, 2021). Amerika Kömür Birliği'nin yıllık raporuna göre ABD'de 2016 yılında üretilen 29 milyon ton FGD alçının \%54'ü alçıpan, \%8'i çimento / beton / asfalt üretiminde kullanılmış ve \%43'ü depolama alanlarında bertaraf edilmiştir (Koralegedara ve ark., 2019). Polonya'da 2019 yılında 3,08 milyon ton FGD alçı üretilmiştir (Baran ve ark., 2021). Hindistan'daki termik santrallerden yılda yaklaşık olarak 8 milyon ton FGD alçı atığının üretildiği bilinmektedir (Bakshi ve ark., 2021).

Uluslararası çeşitli akademik çalışmalar incelendiğinde FGD alçının; yangına dayanıklı panel (Li ve ark., 2015), kompozit malzeme (Bakshi ve ark., 2021) ve çevre dostu kalsiyum sülfo alüminat (CSA) çimentolarının (Xu ve ark., 2017) üretiminde ham madde; yapı malzemeleri üretiminde bağlayıcı malzeme (Mymrin ve ark., 2015); portland çimentosunda geciktirici katkı malzemesi (Caillahua ve Moura, 2018), çevresel açıdan daha temiz beton üretiminde (Jiang ve ark., 2018) ve çimentolu macun dolgu malzemesi (Chen ve ark., 2018) olarak kullanım potansiyelinin yüksek, alternatif bir malzeme olduğu sonucuna varılmıştır. Bunun yanı sıra FGD alçının yapı sektöründe atık ürün olarak değerlendirilmesi, çevresel fayda getireceği (Fort ve Cerný, 2018) ve doğal kaynaklara olan ihtiyacı azaltacağının da bir göstergesidir. 


\section{Yapı Sektöründe Baca Gazı Arıtma Atıklarının Kullanımı}

Türkiye farklı enerji kaynaklarına sahip bir ülke olmasına rağmen, elektrik enerjisinin 2/3'ünü termik santrallerden karşılamaktadır (Avcı, 2015). Türkiye'de elektrik enerjisi üretimi için özellikle kömür yakıtlı termik santrallerin kullanılmasının temel nedeni, kömürün fueloil veya doğalgaz gibi ülkemizde pahalı ya da az miktarda bulunan yakıtlara göre daha ekonomik olmasıdır (Karaca ve ark., 2009). Termik santrallerin bacalarından çıkan kükürt içerikli gazlar havaya karışarak çevre kirliliğine neden olmaktadır. Türkiye'de çevre mevzuatları kapsamında termik santrallerin neden olduğu hava kirliliğini önleyebilmek için yönetmelikler bulunmaktadır. Bunlardan 'Sanayi Kaynaklı Hava Kirliliğinin Kontrolü Yönetmeliği’ 03.07.2009 tarihli 27277 sayılı Resmi Gazetede ve baca gazları ile ilgili emisyon sınır değerlerinin belirtildiği 'Büyük Yakma Tesisleri Yönetmeliği' ise 08.06.2010 tarihli 27605 sayılı Resmi Gazetede yayımlanmıştır. Sanayi Kaynaklı Hava Kirliliğinin Kontrolü Yönetmeliği 20.12.2014 tarihli 29211 sayılı Resmi Gazete ile güncellenmiştir. Söz konusu yönetmeliğin amacı; sanayi ve enerji üretim tesislerinin faaliyeti sonucu atmosfere yayılan is, duman, toz, gaz, buhar ve aerosol halindeki emisyonları kontrol altına almak; insanı ve çevresini hava alıcı ortamındaki kirlenmelerden doğacak tehlikelerden korumak; hava kirlenmeleri sebebiyle çevrede ortaya çıkan umuma ve komşuluk münasebetlerine önemli zararlar veren olumsuz etkileri gidermek ve bu etkilerin ortaya çıkmamasını sağlamaktır (ÇŞB, 2014).

Türkiye'deki kömür yakıtlı termik santrallerindeki baca gazlarının zararlı etkilerini azaltabilmek amacıyla; FGD sistemi 1990'lı yıllar sonrasında kurulmaya başlanmıştır. İlk olarak 1991 yılında Çayırhan Termik Santrali'ne kurulan tesis ile kükürt giderme verimi \%98'in üzerinde sağlanmıştır (Yavuzdoğan ve ark., 1997). Bu sistemler; daha sonra 1999 yılında Orhaneli Termik Santrali'ne (Tülek, 2007), 2002 yılında Kemerköy Termik Santrali'ne (Aytaç, 2020), 2004 yılında Afşin Elbistan B Termik Santrali’ne (Özdemir, 2013), 2008 yılında Yeniköy Termik Santrali’ne (Aytaç, 2020) kurulmuş ve faaliyete geçirilmiştir. FGD sisteminin yatırım ve işletme maliyetlerinin düşük olması önem arz etmektedir (Çift, 2008). 2016 yılı verilerine göre; kamu ve özel sektördeki yerli kömür yakıtlı termik santrallerin \%48'lik bölümünde kükürt arıtma sistemi bulunmamaktadır. Mevcut durumda, kükürt arıtma sistemi bulunan eski santrallerde ise, sınır emisyon değerlerinin sağlanmasında büyük sorunlar ortaya çıkmakta ve bu sorunlar nedeniyle santrallerde elektrik üretim kapasitesi düşmekte ve büyük maddi kayıplar oluşmaktadır. Türkiye'de kükürt ve azot oksit arıtma sistemlerinin aksine kömür yakıtlı termik santrallerin tamamında toz tutma sistemleri bulunmaktadır (Dikmen, 2017). Baca gazı arıtma sistemi olmayan Seyitömer ve Tunçbilek Termik Santralleri 
kapatılmış ve tesislerin çevresel etkilerini azaltabilmek için yapılan iyileştirme çalışmaları ile yeniden faaliyete başlamıştır (URL-2, 2021).

FGD atıkları olarak nitelendirilen; FGD alçı, uçucu kül, taban külleri ve kazan cürufu gibi maddelerin miktarları değişiklik göstermektedir. Ülkemizde kullanılan linyit kömürlerinin \%35-40 oranında kül açığa çıkardıkları bilinmekte olup, toplam FGD atık miktarı tam olarak bilinmemektedir. TÜİK tarafından yürütülen 2018 yılı anket çalışmasına göre; kömür yakıtlı 23 termik santralden toplam 23.315.821 ton cüruf ve uçucu kül atığı oluşmuştur (ÇŞB, 2020). Türkiye'deki FGD atıklarının kullanımı ile ilgili olarak Çayırhan, Soma, Orhaneli, Seyit Ömer ve Kangal Termik Santralleri'nde üretilen atıkların deneysel olarak incelendiği çeşitli akademik çalışmalar bulunmaktadır. Bu çalışmaların sonuçlarına göre FGD atıklarının; çeşitli özellikte alçı (Toroğlu vd., 1997), zemin stabilizayon malzemesi (Özbayoğlu ve Gürel, 1997; Tülek, 2007), duvar ve döşemeler için kompozit kaplama malzemesi (Yıldız ve Yıldız, 2003), \%90 oranında atık esaslı tuğla (Yazıc1, 2004; Yüksek ve Kaya, 2017), gözenekli hafif yapı malzemesi (Demir, 2005), taşıyıcı olmayan panel elemanı (Yazıcı, 2005), çimento (Kökipek, 2010) ve yalıtım sıvası (Biçer, 2020) üretiminde ham madde olarak kullanılabileceği görülmüştür.

Bu çalışmada; Türkiye'de FGD sistemine sahip ve faaliyetine devam eden büyük ölçekli (kurulu gücü 50MW ve üzeri) kömür yakıtlı 21 termik santralden 7 tesis ile iletişime geçilmiş ve geri dönüş sağlayan 3 termik santralin çalışmaları değerlendirilmiştir. Çalışma kapsamında; Orhaneli Termik Santrali (Bursa), İsken Sugözü Termik Santrali (Adana) ve Zetes-Eren Termik Santrali (Zonguldak) yetkilileri ile FGD atıklarının yapı sektöründeki kullanım durumunu tespit etmeye yönelik görüşmeler yapılmıştır.

Orhaneli Termik Santrali, 210 MW kurulu gücü ile Türkiye'nin 26. büyük linyit yakıtlı termik santralidir (Enerji Atlası, 2019). $\mathrm{SO}_{2}$ parametresi için; yakıt ısıl gücü $100 \mathrm{MW}$ ile $300 \mathrm{MW}$ arasında olan tesislerde \%75'lik kükürt azaltma sağlanmalıdır (ÇŞB, 2014). Santraldeki FGD sistemi, çevresel etkileri azaltabilmek için tesise sonradan eklenmiştir. FGD sisteminde alçıtaşı susuzlaştırma işleminin maliyetli olması nedeniyle kurulan sistem sadece çevreye zararlı gazların verilmesini önlemektedir (Not-1, 2019). Yazıcı (2004)'nın çalışmasına göre; Orhaneli Termik Santrali'nin tam kapasite çalışması ile yıllık 1,5 milyon ton kömür yakılmakta 360-400 bin ton uçucu kül, 90-100 bin ton taban külü ve yaklaşık 100 bin ton FGD alçı oluşmaktadır. Bursa Çevre ve Şehircilik İl Müdürlüğü tarafından hazırlanan Bursa İli 2019 yılı Çevre Durumu Raporu’na göre; Orhaneli Termik Santrali'nde yıllık 1.899.121 kg kömür kullanılmış ve 417.959 kg uçucu kül ile $179.125 \mathrm{~kg}$ cüruf oluşmuştur (Bursa İli Çevre Raporu, 2020). Tesiste üretilen FGD atıklarından 
uçucu küller TS EN 451 standardını sağlayamadığı için yapı sektöründe kullanılmamakta ve bu atıklar kül barajına veya sulu depolama alanlarında gönderilmektedir. Tesiste oluşan atıkların genel değerlendirmesi kapsamında; kaynak eksikliğinin olması, tesisin bulunduğu bölgedeki altyap1 çalışmalarının yetersiz olması ve alıcı firmaların eksikliği gibi nedenlerden kaynaklı olarak mevcut atıklar yeniden kullanılamamakta ve atıkların bertaraf edilmesi için depolama işlemi yapılmaktadır (Not-1, 2019).

İsken Sugözü Termik Santrali, 1308 MW kurulu gücü ile Türkiye’nin 5. büyük ithal kömür yakıtlı termik santralidir (Enerji Atlası, 2019). $\mathrm{SO}_{2}$ parametresi için; yakıt 1sıl gücü $500 \mathrm{MW}$ ve üzeri olan tesislerde \%94'lük kükürt azaltma sağlanmalıdır (ÇŞB, 2014). Santraldeki FGD sistemi, çevrenin korunması ve geliştirilmesi açısından kullanılmaktadır. Adana Çevre ve Şehircilik İl Müdürlüğü tarafından hazırlanan Adana İli 2019 yılı Çevre Durumu Raporu'na göre; İsken Sugözü Termik Santrali'nde yıllık 2.500.000 ton kömür kullanılmış ve 256.000 ton uçucu kül ile 17.000 ton cüruf oluşmuştur. 2019 yılında santralden çıkan 188.600 ton kül ve cüruf geri kazanılarak yan ürün ve alternatif ham madde olarak lisanslı firmalar tarafından değerlendirilmiştir (Adana İli Çevre Raporu, 2020). Tesisteki uçucu küller TS EN 451 standardı kapsamında değerlendirilirken, alçıtaşı için standart mevcut değildir. Fakat her iki ürün için G Ulusal Teknik Onay Belgesi vardır. Atık alçı taşı ihraç edilmektedir. Tesiste oluşan atıkların genel değerlendirmesi kapsamında; atık ürünlerin yeniden kullanımı mevcuttur. FGD atıkları yapı sektöründe yapı malzemesi üretiminde ham madde ve katkı maddesi olarak kullanılmaktadır (Not-2, 2019). Şekil 4'te Sugözü Termik Santrali'nin akım şeması gösterilmektedir (URL-3 ,2019).

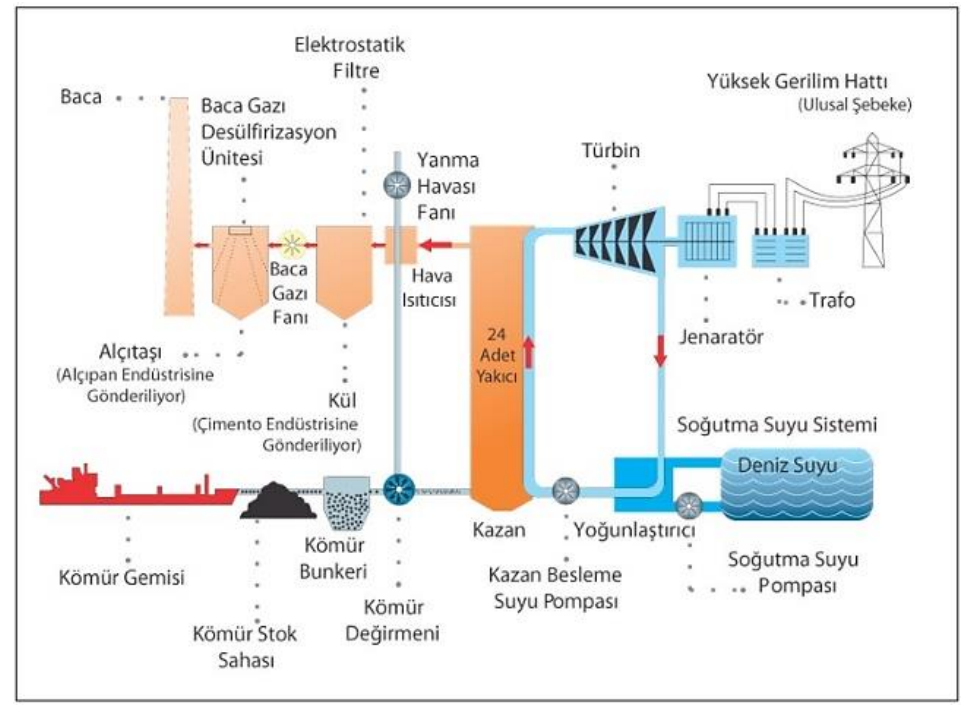

Şekil 4. Sugözü Termik Santrali Akım Şeması 
Zetes-Eren Termik Santrali, 2790 MW kurulu gücü ile Türkiye'nin en büyük ithal kömür yakıtlı termik santralidir (Enerji Atlası, 2019). $\mathrm{SO}_{2}$ parametresi için; yakıt 1sıl gücü $500 \mathrm{MW}$ ve üzeri olan tesislerde \%94'lük kükürt azaltma sağlanmalıdır (ÇŞB, 2014). Santraldeki FGD sistemi, teknolojik olarak gelişmiş durumdadır. Tesiste, kömür yakma veriminin çok yüksek olmasını sağlayan süper kritik ve akışkan yataklı kazanlar kullanılmaktadır. Yüksek kaliteli kömür kullanılması sonucunda ortaya çıkan kireç taşı tesis içerisinde işlemden geçirilerek kurutma sistemine dahil edilmektedir (Not-3, 2019). Zonguldak Çevre ve Şehircilik İl Müdürlüğü tarafindan hazırlanan Zonguldak İli 2019 yılı Çevre Durumu Raporu'na göre; Zetes-Eren Termik Santrali'nde y1llık 6.581 .656 ton kömür kullanılmış ve 61.576 ton uçucu kül ile 29.012 ton cüruf oluşmuştur (Zonguldak İli Çevre Raporu, 2020). Tesiste üretilen atıklardan uçucu kül miktarı alçı taşına göre en az 4 kat daha fazladır. Tesiste oluşan atıkların yapı sektöründe değerlendirilebilmesi için TS standardını sağlaması ve Uygunluk Belgesi alması gerekmektedir. FGD alçının kullanımı için belli bir standart bulunmamakta olup, alçının değerlendirilebilmesi için ürünün saflığı, nemi, kristal suyu ve yoğunluğu gibi kriterler göz önüne alınmaktadır. Tesiste oluşan atıkların genel değerlendirmesi kapsamında; baca gazı atıklarının \%100 oranında geri dönüşümü/ yeniden kullanımı sağlanmaktadır. Alçıtaşı ve yan ürünler anlaşmalı firma tarafından alınmaktadır. Alıcı firma, ürünlerin beton, tuğla ve dolgu malzemesi olarak kullanımını sağlamak için yurtiçi ve yurtdışında satışını gerçekleştirmektedir. FGD atıklarından özellikle uçucu küller çimento üretiminde, FGD alçı ise alçı levha üretiminde kullanılmaktadır (Not-3, 2019).

Yapılan çalışmalar sonucunda; FGD atıklarının inşaat uygulamalarında yapısal dolgu, yol temel tabakası, taşıyıcı olmayan blok eleman yapımında, alçı-alçı panel üretiminde, beton, harç ve çimento üretiminde kullanılabilme durumu mevcuttur. Termik santrallerdeki kömür yanması sonucu oluşan ürünlerin yapı malzemesi olarak değerlendirme olanakları Şekil 5'te şematik olarak gösterilmiştir.

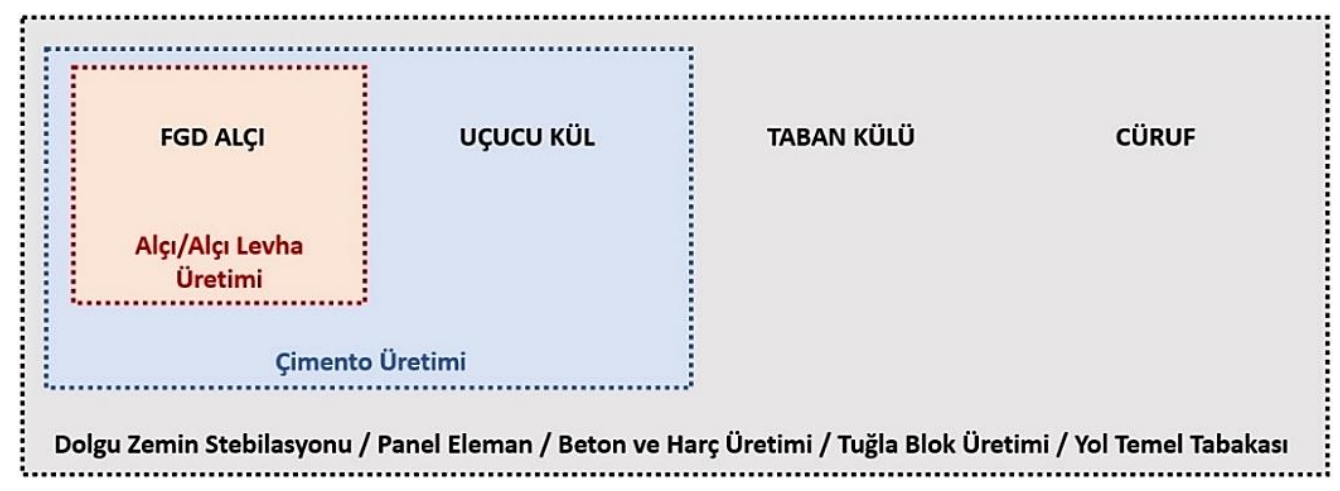

Şekil 5. FGD Atıklarının İnşaat Sektöründe Kullanım 


\section{Sonuç ve Değerlendirme}

Enerji ihtiyacını karşılayabilmek amacı ile kurulan kömür yakıtlı termik santrallerde fosil yakıtların yanması sonucu oluşan kül, çözünemeyen bileşikler, sülfür içerikli gazlar gibi atıklar; hava, su ve toprak kirliliğine neden olarak çevre ve insan sağlığını olumsuz yönde etkilemektedir. Çevresel sorunları azaltabilmek için enerji tesislerinde FGD sistemlerinin kurulması önemli bir adımdır. $\mathrm{Bu}$ sistemlerin kullanılması sonucunda ortaya çıkan ürünler, FGD atıkları olarak tanımlanmaktadır. Atık maddelerin yeniden kullanımı veya geri dönüşümüne yönelik çeşitli çalışmalar mevcuttur ve çevresel olumsuzlukları en az seviyeye indiren uygulamalar ön plana çıkmaktadır. FGD ürünlerinin yapı endüstrisinde kullanılması malzeme üretimi açısından fayda sağlamaktadır. Uçucu kül ve doğal alçı ile eş değer özellikler gösteren FGD alçı, FGD sistemindeki en fazla üretim atığı oluşturan ürünlerdir. Bu ürünlerden özellikle alçı üreticileri tarafından talep edilen FGD alçı; endüstriyel olarak alçı levha, alçı blok, zemin şapları, sıva, beton ve çimento üretiminde kullanılabilmektedir.

FDG ürünlerinin kullanımı konusundaki uygulamalar; İngiltere, ABD, Japonya gibi ülkelerde mevcut iken, Türkiye'de ise son dönemlerde yaygınlaşmaktadır. Araştırma kapsamında; Bursa, Adana ve Zonguldak'taki kömür yakıtlı 3 termik santralin baca gazı arıtma çalışmalarına yönelik veriler Tablo 3 'te gösterilmiştir.

Tablo 3. Termik Santrallerdeki Baca Gazı Arıtma Çalışmaları

\begin{tabular}{|c|c|c|c|c|c|c|c|c|}
\hline & $\begin{array}{c}\text { Faaliyet } \\
\text { Yılı }\end{array}$ & $\begin{array}{c}\text { Yakıt } \\
\text { Tipi }\end{array}$ & $\begin{array}{c}\text { Kurulu } \\
\text { Gücü } \\
\text { (MW) }\end{array}$ & $\begin{array}{c}\text { Kazan } \\
\text { Tipi }\end{array}$ & $\begin{array}{c}\text { Baca Gazı } \\
\text { Arıtma } \\
\text { Sistemi }\end{array}$ & $\begin{array}{c}\text { Teknik } \\
\text { Olanaklar }\end{array}$ & $\begin{array}{c}\text { Baca Gazı } \\
\text { Arıtma } \\
\text { Atıkları }\end{array}$ & $\begin{array}{c}\text { Baca Gazı } \\
\text { Arıtma } \\
\text { (FGD) } \\
\text { Atıklarının } \\
\text { Durumu }\end{array}$ \\
\hline $\begin{array}{c}\text { Orhaneli } \\
\text { Termik } \\
\text { Santrali }\end{array}$ & 1992 & Linyit & 210 & $\begin{array}{l}\text { Püskürtme } \\
\text { Kömür }\end{array}$ & $\begin{array}{l}\text { Mevcut } \\
\text { (Tesise } \\
\text { sonradan } \\
\text { eklenmiş) }\end{array}$ & Sinırlı & $\begin{array}{l}\text { Standarda } \\
\text { Uygun } \\
\text { Değil }\end{array}$ & $\begin{array}{c}\text { Depolama } \\
\text { alanlarına } \\
\text { gönderiliyor. }\end{array}$ \\
\hline $\begin{array}{c}\text { İsken } \\
\text { Sugözü } \\
\text { Termik } \\
\text { Santrali }\end{array}$ & 2004 & $\begin{array}{c}\text { İthal } \\
\text { Kömür }\end{array}$ & 1308 & $\begin{array}{c}\text { Püskürtme } \\
\text { Toz } \\
\text { Kömürlü } \\
\text { Kazan }\end{array}$ & Mevcut & Yeterli & $\begin{array}{l}\text { Standarda } \\
\text { Uygun }\end{array}$ & $\begin{array}{c}\text { Alternatif ham } \\
\text { madde olarak } \\
\text { yeniden } \\
\text { kullaniliyor. }\end{array}$ \\
\hline $\begin{array}{c}\text { Zetes- } \\
\text { Eren } \\
\text { Termik } \\
\text { Santrali }\end{array}$ & 2010 & $\begin{array}{c}\text { İthal } \\
\text { Kömür }\end{array}$ & 2790 & $\begin{array}{c}\text {-Akışkan } \\
\text { Yataklı } \\
\text { Kazan } \\
\text {-Süper } \\
\text { Kritik } \\
\text { Kazan }\end{array}$ & Mevcut & Yeterli & $\begin{array}{l}\text { Standarda } \\
\text { Uygun }\end{array}$ & $\begin{array}{c}\text { Alternatif ham } \\
\text { madde olarak } \\
\text { yeniden } \\
\text { kullaniliyor. }\end{array}$ \\
\hline
\end{tabular}


Orhaneli, İsken Sugözü ve Zetes-Eren Termik Santrallerinin baca gazı arıtma sistemleri değerlendirildiğinde; tesislerdeki yakıt tipi ve kazan türleri değişiklik göstermektedir. Tesislerin üretim kapasitesi ile kullanılan kömürün kükürt içeriğine ek olarak kazanların teknolojik açıdan gelişmiş olması kömürün yakma verimini arttırarak oluşan atık ürünlerin özelliklerini etkilemektedir. Bu duruma bağlı olarak, Orhaneli Termik Santrali'ndeki baca gazı arıtma atıkları kullanım standartlarını sağlayamadığı için depolama alanlarına gönderilmektedir. Tesisler faaliyetleri açısından incelendiğinde; kurulum yılı eski olan termik santraller ile yeni kurulan termik santrallerin fiziki şartları, teknik ve teknolojik olanakları baca gazı arıtma sisteminin verimli çalışmasına etki eden faktörlerdir. Bu kapsamda, İsken Sugözü ve Zetes Eren Termik Santrallerindeki baca gazı arıtma sistemleri tesis ile birlikte kurulduğu için zararlı gazların çevresel etkilerini azaltmanın yanı sıra FGD atıklarının alternatif ham madde olarak yeniden kullanılabilmesini sağlamaktadır. Genel çerçevede, FGD ürünlerinin kullanım olanakları için; atıkların hangi işlem sonucu oluştuğu, içerisinde zararlı element bulunabilme ihtimali ve gerekli standartlara uygunluğu gibi kriterler göz önüne alınmalıdır. Çalışmada, yeni kurulmuş ve teknolojik açıdan gelişmiş kömür yakıtlı termik santrallerdeki FGD atıklarının kullanım durumunun ve yapı sektörü başta olmak üzere çeşitli alanlarda değerlendirilebilme olanaklarının daha yüksek olduğu anlaşılmıştır.

Sonuç olarak; Türkiye'de FGD atıklarını yeni malzeme üretiminde ham madde olarak kullanılmasını sağlamak atık yönetimi uygulamaları açısından olumlu sonuçlar ortaya çıkartacaktır. Ülkemizde FGD atıklarına yönelik hem akademik çalışmaların hem de uygulama faaliyetlerinin geliştirilmesi oldukça önemlidir. FGD atıkları; fiziksel, kimyasal ve mineralojik özelliklerine göre değerlendirilmeli ve inşaat uygulamalarındaki kullanım olanakları arttırılmalıdır. Geri kazanılabilen atık ürünlerin malzeme üretim sürecine dahil edilmesi doğal kaynakların ve enerjinin korunumu, depolama alanlarının daha az kullanımı gibi çevresel ve ekonomik açıdan sürdürülebilirliği sağlayacaktır.

\section{Yazarların Katkısı}

Çalışmada; her iki yazar eşit oranda katkı sunmuştur.

\section{Çıkar Çatışması Beyanı}

Yazarlar arasında herhangi bir çıkar çatışması bulunmamaktadır. 


\section{Araştırma ve Yayın Etiği Beyanı}

Yapılan çalışmada, araştırma ve yayın etiğine uyulmuştur.

\section{Teşekkür}

Gebze Teknik Üniversitesi Mimarlık Anabilim Dalı Doktora Programında 2018-2019 EğitimÖğretim Y1lı Güz Dönemi açılan Sürdürülebilir Yap1 Malzemeleri dersi kapsamında yapılan bu çalışmaya değerli katkılarından dolayı Bursa Orhaneli Termik Santrali, Adana İsken Sugözü Termik Santrali ve Zonguldak Zetes-Eren Santrali yetkililerine teşekkürlerimizi sunarız.

\section{Kaynaklar}

Adana İli Çevre Raporu, (2020). Adana İli 2019 Yılı Çevre Durum Raporu. T. C. Adana Çevre ve Şehircilik Il Müdürlügü, Türkiye. https://webdosya.csb.gov.tr/db/ced/icerikler/adana_-2019_-cdr20201023092541.pdf, (Erişim Tarihi:10 Mayis 2021).

Avc1, S., (2015). Türkiye'de Termik Santraller ve Çevresel Etkileri. İstanbul Üniversitesi Coğrafya Dergisi, $13,1-26$.

Aytaç, O., (2018). Kömüre Dayalı Termik Santraller Çevre ve Yeni Projeler. Türkiye’nin Enerji Görünümü 2018 Oda Raporu, TMMOB Makina Mühendisleri Odas1, Yayın No: MMO/691, 263-278.

Aytaç, O., (2020). Ülkemizdeki Kömür Yakıtlı Santraller Çevre Mevzuatıyla Uyumlu Mu?. Türkiye'nin Enerji Görünümü 2020 Oda Raporu, TMMOB Makina Mühendisleri Odas1, Yayın No: MMO/717, 237-254.

Bakshi, P., Pappu, A., Kumar, M., (2021). Flue Gas Desulphurization (Fgd) Gypsum Waste - Recycling Opportunity. Journal of the Institution of Engineers (India): Environmental Engineering Division, 4, 68-73.

Baran, E., Czernik, S., Hynowski, M., Michalowski, B., Piasecki, M., Tomaszewska, J., Michalak, J., (2021). Quantifying Environmental Burdens of Plasters Based on Natural vs. Flue Gas Desulfurization (FGD) Gypsum, Sustainability. https://doi.org/10.3390/su13084298.

Biçer, A., (2020). Thermal Properties of Gypsum Plaster with Fly Ash, International Journal of Eastern Anatolia Science Engineering and Design, 2(1),120-133.

Bursa İli Çevre Raporu, (2020). Bursa İli 2019 Yı1ı Çevre Durum Raporu. T. C. Bursa Çevre ve Şehircilik İl Müdürlügü, Türkiye. https://webdosya.csb.gov.tr/db/ced/icerikler/bursa 2019 cevre durum raporu20201217210215.pdf, (Erişim Tarihi:10 Mayıs 2021).

Caillahua, M.C., Moura, F.J., (2018). Technical Feasibility for Use of Fgd Gypsum as an Additive Setting Time Retarder for Portland Cement. Journal of Materials Research and Teknology, 7(2), 190-197.

Chen, Q., Zhang, Q., Qi, C., Fourie, A., Xiao, C., (2018). Recycling Phosphogypsum and Construction Demolition Waste for Cemented Paste Backfill and its Environmental Impact. Journal of Cleaner Production, 186, 418-429.

Coppola, L., Belz, G., Dinelli, G., Collepardi, M., (1996). Prefabricated Building Elements Based on FGD Gypsum and Ashes From Coal-Fired Electric Generating Plant. Materials and Structures, 29, 305-311.

Çift, B.D., (2008). Linyit Kullanılan Termik Santrallerde Baca Gazı Desülfürizasyon Proseslerinin Ekonomik ve Teknik Analizi. Doktora Tezi. İstanbul Teknik Üniversitesi, Fen Bilimleri Enstitüsü, İstanbul.

ÇŞB, (2014). T.C. Çevre ve Şehircilik Bakanlığı, Sanayi Kaynaklı Hava Kirliliğinin Kontrolü Yönetmeliği. 20 Aralık 2014 tarih ve 29211 sayılı Resmî Gazete, Ankara, Türkiye. 
ÇŞB, (2015). T.C. Çevre ve Şehircilik Bakanlığı, Atık Yönetimi Yönetmeliği. 2 Nisan 2015 tarih ve 29314 say1lı Resmî Gazete, Ankara, Türkiye.

ÇŞB, (2016). T.C. Çevre ve Şehircilik Bakanlığı, Sektörel Atık Kılavuzları-Termik Santraller. "Endüstriyel Atıkların Sektörel Yönetimi Kapsamında Atık Üretim Faktörlerinin Belirlenmesi ve Sektör Kılavuzlarının Hazırlaması", Proje Yöneticisi: Prof. Dr. Ülkü Yetiş, ODTÜ Çevre Mühendisliği Bölümü. https://webdosya.csb.gov.tr/db/cygm/editordosya/Termik_Santraller_Kilavuzu.pdf (Erişim Tarihi: 19 May1s 2021).

ÇŞB, (2020). T.C. Çevre ve Şehircilik Bakanlığı, 6. Türkiye Çevre Durum Raporu. https://webdosya.csb.gov.tr/db/ced/icerikler/tc-dr_2020-rapor-v18-web-20210217135643.pdf, (Erişim Tarihi: 4 Mart 2021).

Enerji Atlas1, (2019). Kömür ve Linyit Yakıtlı Termik Santraller. https://www.enerjiatlasi.com/komur/, (Erişim Tarihi: 9 Mart 2019).

EÜAŞ, (2020). 2019 Y1lı Elektrik Üretim ve Ticaret Sektörü Raporu. Strateji Geliştirme Dairesi Başkanlığ1, Stratejik Planlama Müdürlüğü, Türkiye.

Demir, İ., (2005). Uçucu Külün Hafif Yap1 Malzemesi Üretiminde Kullanılması. Yapı Teknolojileri Elektronik Dergisi, 2005 (1), 21-24.

Dikmen, Ç., (2017). Türkiye'de termik santraller 2017. TMMOB Makine Mühendisleri Odası (Ed.), Kömür yakıtlı termik santrallerin çevreye olumsuz etkileri ve bu etkilerin bertarafı. (s.263-276), Ankamat Matbaacıllk San. Limited Şirketi, Ankara.

Dunster, A.M., (2007). Flue Gas Desulphurisation (Fgd) Gypsum in Plasterboard Manufacture. Characterisation of Mineral Wastes, Resources and Processing Technologies - Integrated Waste Management for the Production of Construction Material, WRT 177 / WR0115. https://pdf4pro.com/amp/view/plasterboard-fgd-gypsum-smartwaste-99d07.html, (Erişim Tarihi: 3 Aralık 2018).

Fort, J., Cerný, R., (2018). Carbon Footprint Analysis of Calcined Gypsum Production in the Czech Republic. Journal of Cleaner Production,177, 795-802.

Jiang, L., Li, C., Wang, C., Xu, N., Chu, H., (2018). Utilization of Flue Gas Desulfurization Gypsum as an Activation Agent for High-Volume Slag Concrete. Journal of Cleaner Production, 205, 589-598.

Karaca, A., Türkmen, C., Arcak, S., Haktanır, K., Topçuoğlu, B., Yıldız, H., (20099. Çayırhan Termik Santralı Emisyonlarının Yöre Topraklarının Bazı Ağır Metal ve Kükürt Kapsamlarına Etkilerinin Belirlenmesi. Ankara Üniversitesi Çevrebilimleri Dergisi, 1(1), 25-41.

Koralegedara, N. H., Pinto, P. X., Dionysiou, D. D., Al-Abed, S. R., (2019). Recent Advances in Flue Gas Desulfurization Gypsum Processes and Applications - A Review, Journal of Environmental Management. doi: 10.1016/j.jenvman.2019.109572

Kökipek, B., (2010). Suni Alçının Çimento Üretiminde Kullanılabilirliği. Yüksek Lisans Tezi. Çukurova Üniversitesi, Fen Bilimleri Enstitüsü, Adana.

Li, J., Zhuang, X., Leiva, C., Cornejo, A., Font, O., Querol, X., Moeno, N., Arenas, C., Fernandez-Pereira, C., (2015). Potential Utilization of FGD Gypsum and Fly Ash From a Chinese Power Plant for Manufacturing Fire-Resistant Panels. Construction and Building Material, 95, 910-921.

Mymrin, V.A., Alekseev, K.P., Nagalli, A., Catai, R.E., Romano, C.A., (2015). Hazardous PhosphorGypsum Chemical Waste as a Principal Component in Environmentally Friendly Construction Materials. Journal of Environmental Chemical Engineering, 3, 2611-2618.

Not-1, (2019). Bursa- Orhaneli Termik Santrali Görüşme Notları. (19 Mart 2019).

Not-2, (2019). Adana- İsken Sugözü Termik Santrali Görüşme Notları. (30 Nisan 2019).

Not-3, (2019). Zonguldak- Zetes Eren Termik Santrali Görüşme Notları. (19 Mart 2019).

Özbayoğlu, F., Gürel, A., (1997). Çayırhan Termik Santrali Desülfojipslerinin Stabilizasyon Malzemesi Olarak Kullanılması. Alçıder (Ed.), II. Ulusal Alçı Kongresi Bildirileri. İstanbul, Türkiye. http://www.alcider.org.tr/docs/kongre2.pdf, (Erişim Tarihi: 2 Ocak 2019). 
Özdemir, Y., (2013). Afşin- Elbistan Termik Santrallerinin Çevre Kirliliği Üzerindeki Etkileri: Mesafe Tabanlı Algı Analizi. Yüksek Lisans Tezi. Kahramanmaraş Sütçü İmam Üniversitesi, Fen Bilimleri Enstitüsü, Kahramanmaraş.

Tamzok, N., (2017). Türkiye'de termik santraller 2017. TMMOB Makine Mühendisleri Odası (Ed.), Yerli kömüre dayalı termik santral potansiyeli, darboğazlar ve çözüm önerileri. (s.135-145). Ankamat Matbaacilık San. Limited Şirketi, Ankara.

TETAŞ, (2018). 2017 Y1lı Sektör Raporu, Türkiye Elektrik ve Ticaret A.Ş. Genel Müdürlügüu. Ankara, Türkiye.

Toroğlu, İ., Yavuzdoğan, A., Döngel, B., (1997). Sentetik (Kimyasal) Jipslerin Endüstride Kullanımı. II. Endüstriyel Ham Maddeler Sempozyumu (s. 171-176). İzmir, Türkiye.

TÜBİTAK, (2013). Termik Santral Baca Gazı Arıtma Teknolojilerinde Yerli Tasarım ve Imalat Kabiliyetinin Geliştirilmesi (MILLAS) [2013/205]. Bilim ve Teknoloji Yüksek Kurulu 26. Toplantısı Yeni Kararlar. Ankara, Türkiye. https://www.tubitak.gov.tr/sites/default/files/btyk 26 yeni kararlar.pdf, (Erişim Tarihi: 3 Ocak 2019).

Tülek, M., (2007). Kimyasal Atık Alçıların Zemin Stabilizasyonunda Kullanılabilirliğinin Araştırılması. Yüksek Lisans Tezi. Balıkesir Üniversitesi, Fen Bilimleri Enstitüsü, Balıkesir.

URL-1, (2021). European Coal Combustion Products Association e.V. http://www.ecoba.com/ecobaccpprod.html (Erişim Tarihi: 3 Eylül 2021).

URL-2, (2021). https://www.haberler.com/seyitomer-ve-tuncbilek-termik-santralleri-uretime-13130806haberi/, (Erişim Tarihi: 10 Mayıs 2021).

URL-3, (2019). İsken Termik Santrali. http://www.isken.com.tr/akim-semasi.aspx , (Erişim Tarihi: 30 Nisan 2019).

Wright, L., Khatib, J.M., (2016). Sustainability of construction materials. J.M. Khatib (Edt.), Sustainabilility of desulphurised (FGD) waste in construction. (s.683-715), Woodhead Publishing, UK.

Xu, L., Wu, K., Li, N., Zhou, X., Wang, P., (2017). Utilization of Flue Gas Desulfurization Gypsum for Producing Calcium Sulfoaluminate Cement, Journal of Cleaner Production, 161, 803-811.

Yavuzdoğan, A., Toroğlu, İ., Döngel, B., (1997). Desülfojipsum Çamurunun Alçı Üretiminde Kullanımı. Alçıder, (Ed.), II. Ulusal Alçı Kongresi Bildirileri. İstanbul, Türkiye. http://www.alcider.org.tr/docs/kongre2.pdf, (Erişim Tarihi: 2 Ocak 2019).

Yazıcı, H., (2004). Termik Santral Atığı Yapay Alçı-Uçucu Kül-Taban Külü Esaslı Yapı Malzemesi Geliştirilmesi. Doktora Tezi. Dokuz Eylül Üniversitesi, Fen Bilimleri Enstitüsü, İzmir.

Yazıcı, H., (2005). Yapay Alçı-Uçucu Kül Esaslı Bağlayıcıların Mekanik Özellikleri. DEÜ Mühendislik Fakültesi Fen ve Mühendislik Dergisi, 7(1), 65-72.

Yıldız, T., Yıldız, C., (2003). Soma Termik Santrali Uçucu Kül ve Polipropilen Atıklarının Yeni Bir Malzeme Üretiminde Değerlendirilmesi. Pamukkale Üniversitesi Mühendislik Bilimleri Dergisi, 9(2), 163-169.

Yüksek, S., Kaya, S., (2017). Kömür Baca Külü, Kireç ve Jips Ürünlerinden Yap1 Malzemesi Yapımı. APJES Akademik Platform Mühendislik ve Fen Bilimleri Dergisi, 5(3), 58-70.

Zonguldak İli Çevre Raporu, (2020). Zonguldak İli 2019 Yılı Çevre Durum Raporu. T. C. Zonguldak Çevre ve Şehircilik Ill Müdürlüğ̈̈, Türkiye. https://webdosya.csb.gov.tr/db/ced/icerikler/2019 zonguldak cdr-20200914150210.pdf, （Erişim Tarihi:10 Mayıs 2021). 